Formatif: Jurnal Ilmiah Pendidikan MIPA

Vol. 9, No. 4, December 2019, pp. 291-304

p-ISSN: 2088-351X

e-ISSN: 2502-5457

DOI: http://dx.doi.org/10.30998/formatif.v9i4.3522

\title{
The Effect of Implementing Media Computer Based Instruction (Simulation Model) Towards Student's Autonomy in Science Learning
}

\author{
Wiranda Bayu Aditama (*) \\ Universitas Negeri Yogyakarta \\ Satya Sadhu \\ Universitas Negeri Yogyakarta
}

$\begin{array}{ll}\text { Received: } & \text { March 20, } 2019 \\ \text { Revised: } & \text { July 22, 2019 } \\ \text { Accepted: } & \text { October 09, } 2019\end{array}$

\begin{abstract}
Students' autonomy toward teacher during the learning activities leads one-way learning. Consequently, students have less autonomy in the learning activities. Therefore, this research adressed to implement the media computer based instruction (simulation model) in improving the students' autonomy in a science learning. The total participants in this research were 79 of the $4^{\text {th }}$ grade students from a purposively primary schools during the first semester of 2018. They were divided into two groups, namely the experimental group $(n=55)$ and the control group $(n=24)$. The research used a pre-test post-test quasi-experimental method with a nonequivalent control group design. The students' autonomy data were collected by using the observation sheet for each of post-test and pretest which consisted of five aspects i.e. motivation, initiative, confidence, discipline, and responsibility. The independent sample t-test was used statistically to compare the average score of the students' autonomy during the pre-test and post-test. The collected data were analyzed by using SPSS 11.0 statistics program. The findings of the research indicated that computer based instruction (simulation model) affects the students' autonomy significantly in the science learning. Thus, the researcher believes in the further study, the computer based instructions (simulation model) can be intergrated with the model or method in the learning activity to improve the students' autonomy in learning science.
\end{abstract}

Keywords: computer based instruction (simulation model), students' autonomy, science learning, media.

(*) Corresponding Author:

bayuaditamalttk@gmail.com

How to Cite: Aditama, B. A. \& Sadhu, S. (2019). The effect of implementing media computer based instruction (simulation model) towards student's autonomy in science learning. Formatif: Jurnal Ilmiah Pendidikan MIPA, 9 (4): 291-304. http://dx.doi.org/10.30998/formatif.v9i4.3522

\section{INTRODUCTION}

Character education is one of the government's solution in improving the quality of education. According to Presidential Decree Number 87 in 2017 Article 1 Paragraph 1 on the reinforcement of character education, the reinforcement of character education is an educational movement which becomes the educational institution's responsibility to strengthen the student's character along with the harmonization of heart, feeling, thinking, and body supported by the collaboration between educational institution, family, and society as the part of Gerakan Nasional Revolusi Mental/ National Mental Revolution Movement (President Decree, , 2017). It implies that a cultured nation is achieved through the strengthen of values such as religious, honest, tolerant, discipline, persistent, creative, 
Formatif: Jurnal Ilmiah Pendidikan MIPA

Vol. 9, No. 4, December 2019, pp. 291-304

p-ISSN: 2088-351X

e-ISSN: $2502-5457$

DOI: http://dx.doi.org/10.30998/formatif.v9i4.3522

independent/autonomy and etc. Therefore, the reinforcement of character education is needed in creating the cultured nation. Unfortunately, the character education does not work as it is supposed to be. One of the example is the learning activity in a class where the student depends too much on the teacher which means the students' autonomy has not been developed optimally.

Hence, it is very important to develop and apply those three fields for the students in every learning activities. The activities are closely related to the reinforcement of character education program arranged by the government. Among the values itself, there is an autonomy which is close related to the learning activity. Today's curriculum is a studentcentered which means that the students have to be autonomy in order to achieve the goals in learning process. Thus, autonomy becomes the core value in developing student's behavior without ruling out the other character. Pichugova, et. Al. (2016), state that the autonomy students are responsible, flexible, and full of curiosity.

Every schools want to attain the meaningful learning for the students therefore a good quality learning and teaching is needed. Today's learning materials are only advantageous for the teacher and students during the learning activity in a class. The learning materials are supposed to help the students in achieving the learning goals which include the aspect of knowledge, behavior, and skill however today's learning materials work oppositely. Meanwhile, it is seen from the real condition found in the school. Based on the research, the learning materials provided in school have not fully supported the aspect of knowledge, behavior, and skill yet. Besides, based on the discussion, the teacher and students say that the materials provided in the text book is very superficial. In addition, they also say that the text book is not interesting both for the cover and the content. Thus, a learning media which elaborates the students' needs and the students' learning objectives is needed to improve the quality of learning process in a class. Then, the learning materials should employ character education supported with the proper learning model so it can improve the quality of the teaching and learning (Tabor \& Minch, 2013). Kozma (1994) argued that learning by using media is a process where the students and the media interact for accomplishing the learning media.

The use of technology computer for learning can be seen through a computer based instruction. The use of computer based instruction will be beneficial for the teacher during the teaching process at the class since it can be a proper media both for presentation and demonstration. Besides, the students has a higher chance to be autonomus without being dependent on the teacher. The use of computer based instruction will be effective and efficient if it is applied in senior grade, for example the $4^{\text {th }}$ grade students. Piaget states that primary school students are in the concrete operational stage where the way their thinking are dominated by a perception. It means, the students have various experiences, one of them is the experience of operating a computer. In addition, the $4^{\text {th }}$ grade students are able to show good attitude and behavior compared to the junior grade such as the $1^{\text {st }}, 2^{\text {nd }}$, and $3^{\text {rd }}$ grade students. In the 2013 curriculum, the $4^{\text {th }}$ grade students learn about moving object which is related to science. Most schools only concerns in transferring the science knowledge for the students without teaching about the concept of science itself. In other words, the students are triggered with the theory only so that they can work on their exam properly. However, they might not be able to relate it with their surroundings. This problem indicates that science only focuses on understanding the concept without considering the process and the product of the learning process itself.

Based on the background above, this study address to know the effect of implementing the media computer based instruction (simulation model) in improving the students' autonomy in a science learning 
Formatif: Jurnal Ilmiah Pendidikan MIPA

Vol. 9, No. 4, December 2019, pp. 291-304

p-ISSN: 2088-351X

e-ISSN: 2502-5457

DOI: http://dx.doi.org/10.30998/formatif.v9i4.3522

\section{METHOD}

Participants

The participants of this research were the $4^{\text {th }}$ grade students of primary school. The subject was chosen based on the discussion between the researcher with the teacher and the same competences experienced by the students. The subject of this research was divided into three groups, two experimental groups and one control group. The first experimental group consisted of 29 students, the second experimental group consisted of 26 students, and the control group consisted of 24 students. The learning activity in the experimental and control group also uses the same material which is the $8^{\text {th }}$ theme entitled "Daerah Tempat Tinggalku".

\section{Research Design}

In this research, the model simulation of computer based instruction was experimented in a real condition with wider subjects. The researcher collected the data in a primary school by choosing 3 groups, 2 experimental groups and 1 control group. This research used quasi-experimental method with the nonequivalent control-group design. In nonequivalent control group design, the experimental and control groups were not chosen randomly but it was decided by the researcher because both of the classes had the same competences. The method for this research was design nonequivalent control group design which was similar to the pretest-posttest control design and it was modified as pictured on the figure 1 (Sugar \& Brown, 2008).

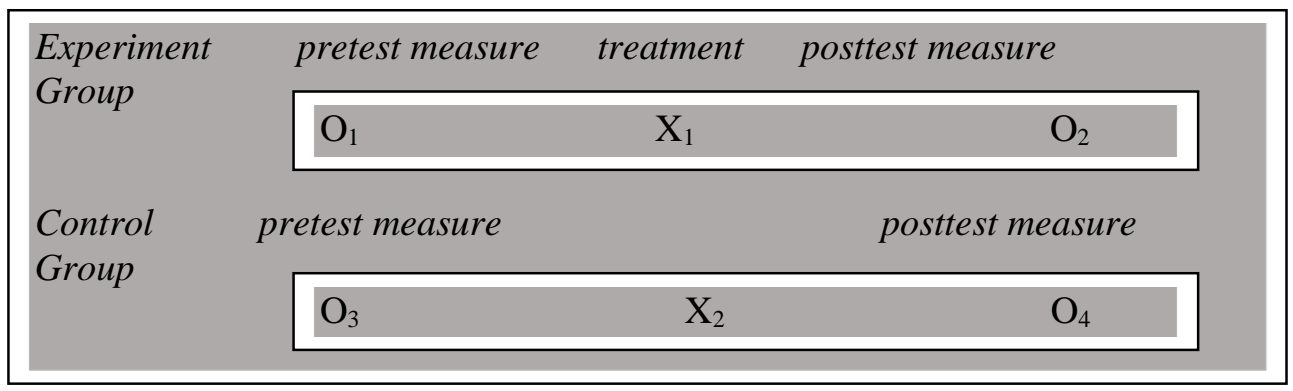

Figure 1. Nonequivalent Control Group Design

$\mathrm{O}_{1}$ : pre-test for the experimental group

$\mathrm{O}_{2}$ : post-test for the experimental group

$\mathrm{X}_{1}$ : the use of computer based instruction simulation model based on the interactive multimedia for the $8^{\text {th }}$ theme learning material about moving object

$\mathrm{O}_{3}$ : pre-test for the control group

$\mathrm{O}_{4}$ : post-test for the control group

$\mathrm{X}_{2:}$ learning activity without the use computer based instruction simulation model.

\section{Media}

The simulation model of computer based instruction has eight steps. For each steps, the instruction was as followed.

1. Introduction

a. In the introduction part, at the beginning of the class, the title of the program was displayed attractively so that the students got curious about what would they learn. Then, this step was also used to give an early introduction about the learning 
Formatif: Jurnal Ilmiah Pendidikan MIPA

Vol. 9, No. 4, December 2019, pp. 291-304

p-ISSN: 2088-351X

e-ISSN: 2502-5457

DOI: http://dx.doi.org/10.30998/formatif.v9i4.3522

materials displayed in the simulation model of computer based instruction simulation model based on the interactive multimedia.

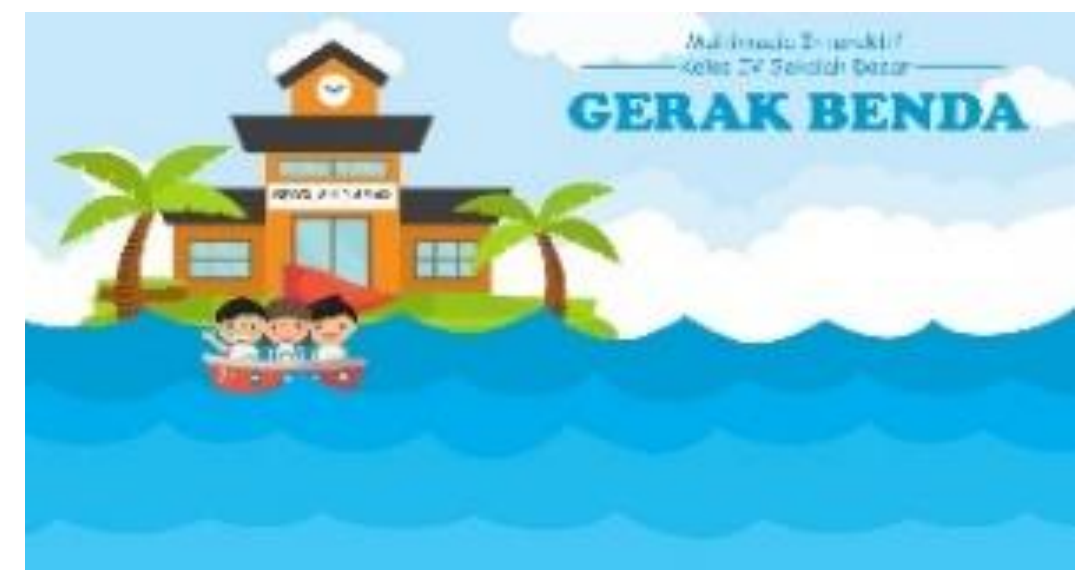

Figure 2. The display of the program title

b. Then, giving an information related to the learning objectives and the competences goal after doing the simulation model of computer based instruction learning. The information was about the core competence, basic competence, learning indicator, and learning objective

c. Showing the instructions of using the program, specifically how to operate the program so the students were able to operate it by themselves.

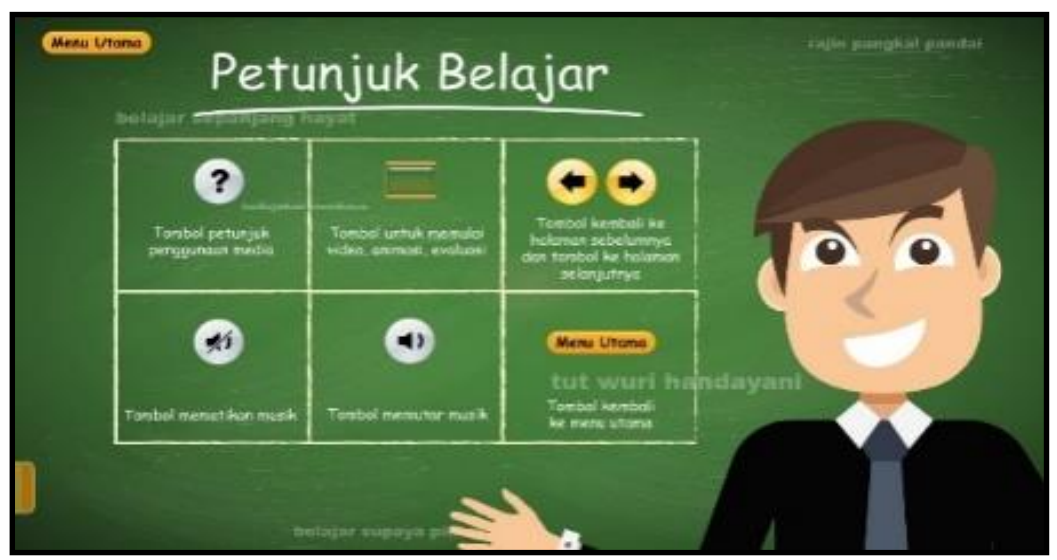

Figure 3. Learning Instructions

2. The next step was showing the information about the simulation $\left(1^{\text {st }}, 2^{\text {nd }}, 3^{\text {rd }}, 4^{\text {th }}\right.$ simulation, etc.) through an animation with the combination of pictures, colors, graphics which captivated students' attention and it also had a clear description about the simulation and the learning materials. 
Formatif: Jurnal Ilmiah Pendidikan MIPA

Vol. 9, No. 4, December 2019, pp. 291-304

p-ISSN: 2088-351X

e-ISSN: 2502-5457

DOI: http://dx.doi.org/10.30998/formatif.v9i4.3522
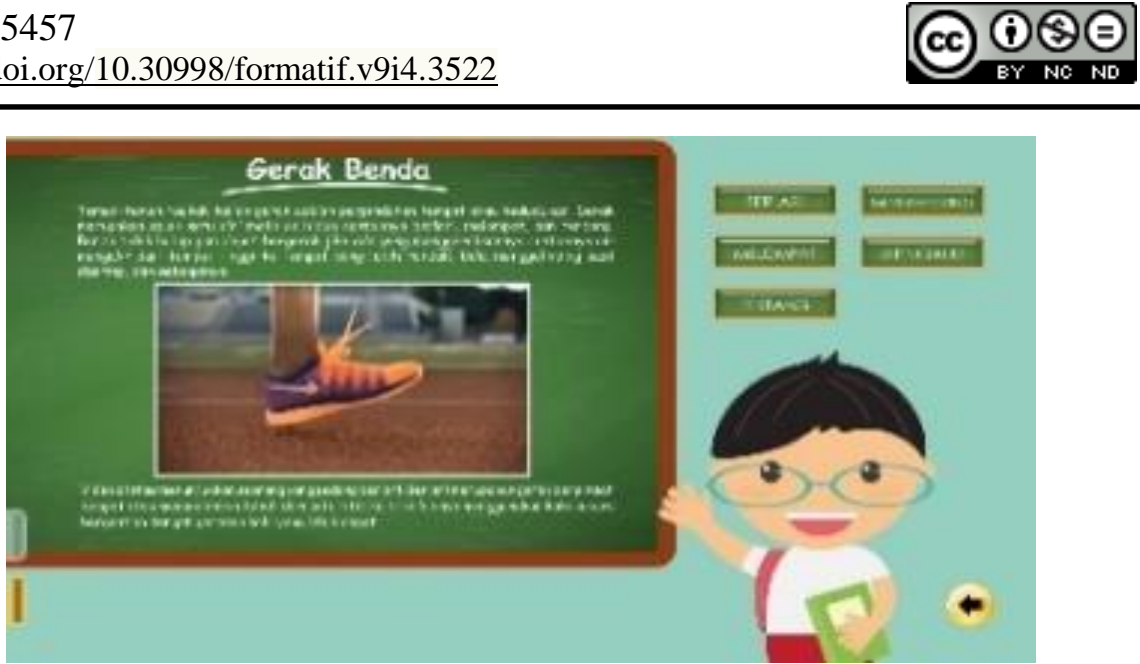

Figure 4. Simulation

3. After the students understood the simulation, they should ask a question and give response towards the other students. In this part, the students should work on evaluation items provided in this program. The total number of the item was 20 multiple choices.

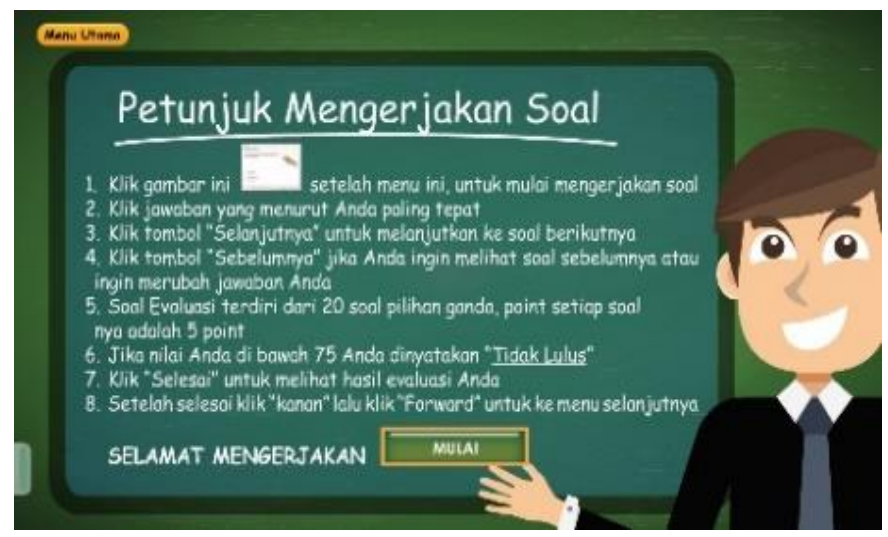

Figure 5. Evaluation

4. The next step was assessing the response. In this step, the computer program responded the students' answer whether it is right or wrong.

5. Giving feedback towards the students' response about the evaluation which meant the students got the feedback directly whether they were succeed or not after finishing the evaluation.

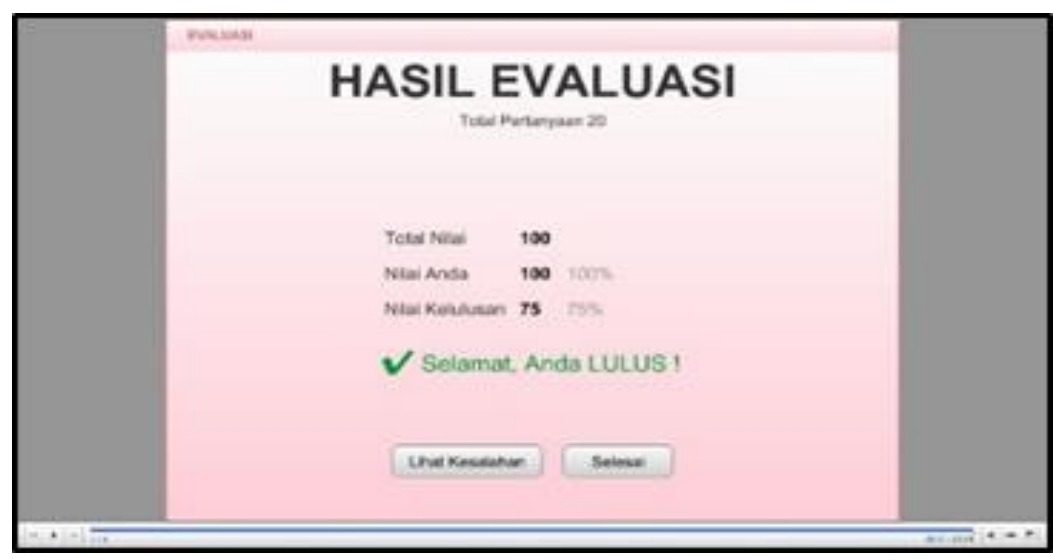

Figure 6. The Result of the Evaluation 
Formatif: Jurnal Ilmiah Pendidikan MIPA

Vol. 9, No. 4, December 2019, pp. 291-304

p-ISSN: 2088-351X

e-ISSN: 2502-5457

DOI: http://dx.doi.org/10.30998/formatif.v9i4.3522

6. The next step was revision. In this part, the students got the information related to their mistakes and the program would provide a response for the students about the correct answer.

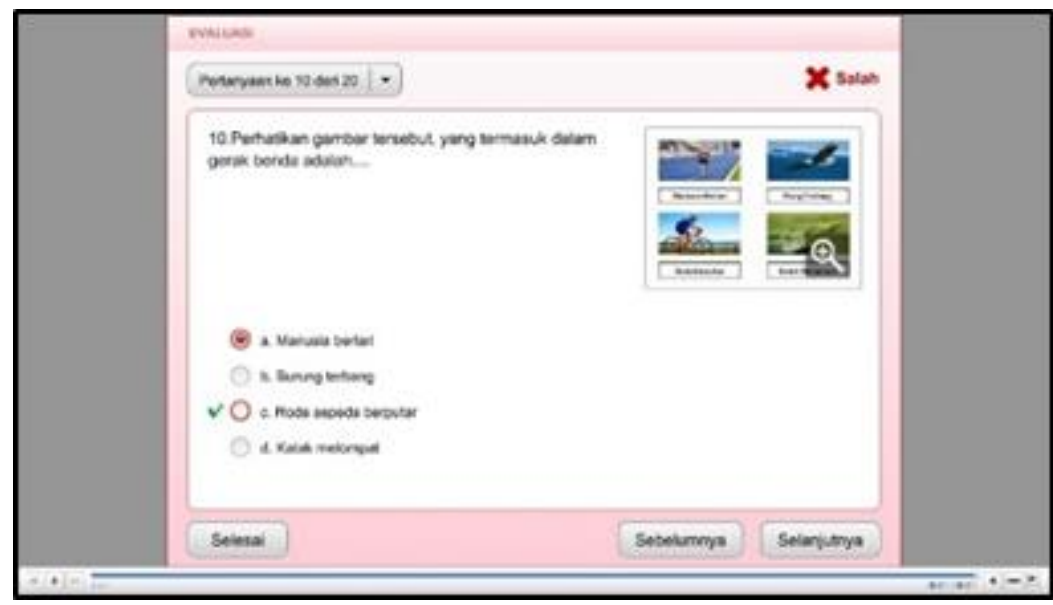

Figure 7. Revision

7. The seventh step was managing the learning. After those several steps, the next important step was the program should be able to divide and manage every provided menu so that the program become more structured and easier to operate.

8. The last step was closing. In this part, the program should have a summary or a conclusion about what had been done by the students. The conclusion was shown to the students, as the user, in form of main points and a paragraph about learning objective.

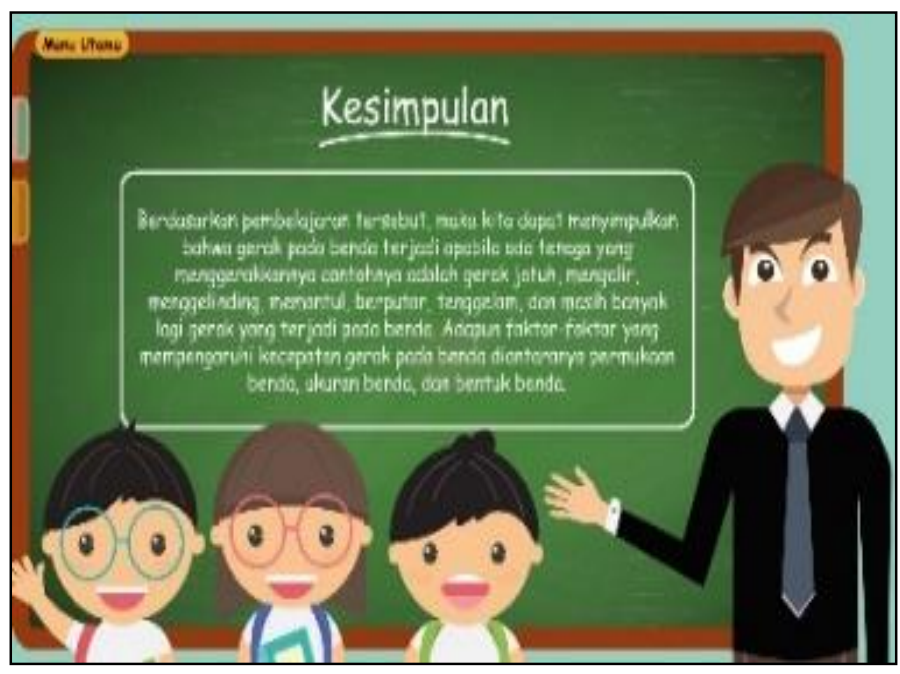

Figure 8. Closing

Before being trialed for the students, the media was validated first by two experts who were the expert of material and media. The assessment of the product by the expert of material was used to know about the quality of the instrument about the product which focused on the material, learning, and the computer based instruction product. The result of the validation was in form of score and suggestion about the product itself. 
Formatif: Jurnal Ilmiah Pendidikan MIPA

Vol. 9, No. 4, December 2019, pp. 291-304

p-ISSN: 2088-351X

e-ISSN: 2502-5457

DOI: http://dx.doi.org/10.30998/formatif.v9i4.3522

Table 1. The Result of the Assessment Product by the Expert of Substance

\begin{tabular}{cccc}
\hline No & Assessment Criteria & Score & Category \\
\hline 1 & Substance & 34 & Very good \\
2 & Instructional & 36 & Good \\
3 & Language & 23 & Very good \\
\hline & Score Total & 93 & Good \\
\hline
\end{tabular}

The result of the assessment by the expert of material was used to know whether the program and the display were appropriate or not.

Table 2. The Result of the Assessment Product by the Expert of Media

\begin{tabular}{cccc}
\hline No & Assessment Criteria & Score & Category \\
1 & Programming & 12 & Good \\
2 & Apperance & 69 & Good \\
\hline & Score Total & 81 & Good \\
\hline
\end{tabular}

\section{Students' Autonomy Assessment Instrument}

In order to assess the students' autonomy in applying computer based instruction simulation model based on the interactive multimedia, the researcher used observation sheet as the instrument. The instrument was also used to find out the improvement of the students' autonomy. The guideline of the students' autonomy observation could be seen in the following table.

Table 3. Guideline of the Students' Autonomy

\begin{tabular}{ccc}
\hline No & Aspects & Number of Statement \\
\hline 1 & Motivated in learning activities & 3 \\
2 & Dare to take the initiative in learning process & 3 \\
3 & Have confidence in learning activities & 3 \\
4 & Be disciplined in learning activities & 3 \\
5 & Have responsibility & 3 \\
\hline
\end{tabular}

\section{Data Analysis}

Checklist technique with Guttman Scale was used as the data for students' autonomy observation. The data addressed to know the effectiveness of computer based instruction simulation model based on the interactive multimedia in improving the students' autonomy. The steps of the data analysis were as followed.

1. Tabulating all the data of each component from the assessment item provided in the assessment instrument of students' autonomy observation.

2. Measuring the total and average score of each component by using a formula [2].

Annotation:

$$
\mathrm{M}=\frac{\sum f x}{N}(1)
$$

$\mathrm{M}=$ average score

$\Sigma f x=$ total score

$\mathrm{N}=$ total component

3. Conversing the average score to the category score as stated (Riduwan, 2010). 
Formatif: Jurnal Ilmiah Pendidikan MIPA

Vol. 9, No. 4, December 2019, pp. 291-304

p-ISSN: 2088-351X

e-ISSN: 2502-5457

DOI: http://dx.doi.org/10.30998/formatif.v9i4.3522

Tabel 4. Conversion of the Average Score to the Criteria of Students' Autonomy

Observation

\begin{tabular}{cc}
\hline Score Interval & Category \\
\hline $81-100$ & Excellent \\
$61-80$ & Very good \\
$41-60$ & Good \\
$21-40$ & Poor \\
$0-21$ & Very poor \\
\hline
\end{tabular}

After collecting the pre-test data and the post-test data from the students' autonomy observation, the researcher did the hypothesis test about the influence of computer based instruction simulation model based on the interactive multimedia towards students' autonomy in science learning. The data was gain score data. Gain scorer was a data of the students' autonomy improvement. Normalized gain $(N-G a i n /\langle g\rangle)$ was used to decide the criteria of students' autonomy. The category of normalized gain was shown in the following table (Hake, 2017).

Table 5. The Category of Normalized Gain Improvement

\begin{tabular}{cc}
\hline Normalized Average Gain & Category \\
\hline $0.70 \leq \mathrm{g}<1.00$ & High \\
$0.30 \leq \mathrm{g} \leq 0.70$ & Medium \\
$\mathrm{g} \leq 0.30$ & Low \\
\hline
\end{tabular}

The formula of normalized gain used in this research was as followed.

Normalized average gain $\langle g\rangle=\frac{<\text { Gain }\rangle}{\text { maximum possible }<\text { Gain }\rangle}$

The hypothesis test could be done after completing the first assumption test in form of normality test and homogeneity test. The normality test was done to know the spread of the data which was normally distributed. For the normality test, the researcher used Kolmogorov-Smirnov test by using software SPSS 20.0 for windows. The significance $(\alpha)$ for the test was 0.05 so if the significance score was more than $\alpha$ (sig.> 0.05), the data from both groups were distributed normally. Then, the homogeneity test was used to know the data variation from the control and experimental group whether having the same data or homogeneous. For the homogeneity test, the researcher used Levene's Test by using software SPSS 20.0 for windows. The significance $(\alpha)$ for the test was 0.05 so if the significance score was more than $\alpha$ (sig.> 0.05), the data from both groups were homogeneous.

The hypothesis test with independent sample t-test was chosen in order to find out the effectiveness of computer based instruction simulation model based on the interactive multimedia in improving the students' autonomy. Besides, it was also used to find out the significance differences between the experimental and control group. In this research, independent sample t-test was done by using SPPS 20 for Windows. The hypothesis was shown as followed.

$\mathrm{H}_{\mathrm{o}}=$ There is no significance difference between the score of students' autonomy observation between the control and experimental group.

$\mathrm{H}_{\mathrm{a}}=$ There is significance difference between the score of students' autonomy observation between the control and experimental group. 
Formatif: Jurnal Ilmiah Pendidikan MIPA

Vol. 9, No. 4, December 2019, pp. 291-304

p-ISSN: 2088-351X

e-ISSN: 2502-5457

DOI: http://dx.doi.org/10.30998/formatif.v9i4.3522

Hypothesis $\mathrm{H}_{0}$ was concluded if the significance score was $(p)>0.05$, there is no improvement in the students' autonomy. Oppositely, if the significance score was $(p)<0.05$, there is an improvement in the students' autonomy.

\section{RESULTS \& DISCUSSION}

\section{Results}

In this research, the experimental group uses computer based instruction simulation model based on the interactive multimedia. Meanwhile, the control group becomes the standard of comparison which uses the old learning sources. The control and experimental groups have similar characteristic and competence at first. According to the steps of analysis data provided, the result will inform sequentially.

\section{Students' Autonomy Observation}

The autonomy is assessed through the observation. The observation uses Guttman scale where the observer responds to the target students whether it is in accordance with the statement by choosing yes or no statement. The experimental and control groups help the researcher to find out the differences between the students' autonomy in each group related to the computer based instruction simulation model based on the interactive multimedia. The result of the data collection is seen as follow.

The observation is done twice for each class which are before (pre-test) and after (posttest) applying the use of computer based instruction simulation model based on the interactive multimedia. There are five indicators of the students' autonomy observation: 1) Motivation; 2) Initiative; 3) Confidence; 4) Discipline; 5) Responsibility. The observation is done and assessed by the observer. The observation uses Guttman scale by using checklist technique where the observer gives the assessment based on the yes no statements. The average conversion score can be seen in this following table.

Table 6. The Result of Students' Autonomy Observation

\begin{tabular}{ccccccc}
\hline \multirow{2}{*}{ Aspects } & \multicolumn{7}{c}{ Score Average } \\
\cline { 2 - 7 } & \multicolumn{2}{c}{ Experiment Class 1 } & \multicolumn{2}{c}{ Experiment Class 2 } & \multicolumn{2}{c}{ Control Class } \\
\cline { 2 - 7 } & P1 & P2 & P1 & P2 & P1 & P2 \\
\hline 1 & 100 & 100 & 100 & 100 & 100 & 100 \\
2 & 26.43 & 51.72 & 23.07 & 48.71 & 25 & 48.61 \\
3 & 68.6 & 94.25 & 74.35 & 96.15 & 69.44 & 93.05 \\
4 & 16.09 & 79.31 & 28.20 & 88.46 & 18.05 & 70.83 \\
5 & 82.75 & 80.45 & 79.48 & 79.48 & 87.5 & 83.33 \\
\hline Average & 58.85 & 81.14 & 61.02 & 82 & 60 & 79.16 \\
\hline
\end{tabular}

The table above shows that there is an improvement during the first and second students' autonomy observation. It is seen from score done by the experimental and control group Overall, the score of the first experimental group shows that the computer based instruction simulation model based on the interactive multimedia is effective to improve students' autonomy during their learning. Furthermore, the result of standard gain of the observation is seen on the following table. 
Formatif: Jurnal Ilmiah Pendidikan MIPA

Vol. 9, No. 4, December 2019, pp. 291-304

p-ISSN: 2088-351X

e-ISSN: 2502-5457

DOI: http://dx.doi.org/10.30998/formatif.v9i4.3522

Table 7. The Result of Students' Autonomy Observation

\begin{tabular}{ccccc}
\hline \multirow{2}{*}{ No } & \multirow{2}{*}{ Class } & \multicolumn{2}{c}{ Average Score } & \multirow{2}{*}{ Gain Standard } \\
\cline { 3 - 4 } & Pre-test & Post-test & \\
\hline 1 & Control Class & 60 & 79.16 & 0.436 \\
2 & Experiment Class 1 & 58.85 & 81.14 & 0.564 \\
3 & Experiment Class 2 & 61.02 & 82 & 0.561 \\
\hline
\end{tabular}

After getting the data related to the students' autonomy, the researcher does the parametric statistic test as the requirement in full filling the assumption before analyzing the independent sample t-test. Then, two of the prerequisite tests are normality test and homogeneity test.

\section{The Normality Test}

In this research, the researcher uses Kolmogorov-Smirnov (one sample KolmogorovSmirnov) technique with the help of SPSS20 for Windowsprogram in analyzing the normality test. The test focuses on the significance score. If the significance score of the probability is on (P-score) $>0.05$ (alpha significance score), it means the data is normally distributed. Meanwhile if the significance score of the probability is on $(P$-score $)<0.05$ (alpha significance score), it means the data is not normally distributed. According to the result, $\mathrm{H}_{\mathrm{o}}$ is acceptable if the significance score is more than 0.05 and it is rejected if the significance score is less than 0.05 . In short, the result of the normality test on control and experimental group is described in this following table.

Table 8. The Result of Students' Autonomy Normality Test

\begin{tabular}{cccccc}
\hline \multirow{2}{*}{$\begin{array}{c}\text { Gain Score } \\
\text { Control and }\end{array}$} & \multicolumn{5}{c}{ Kolmogorov Smirnov } \\
\cline { 2 - 6 } Experiment Class & 79 & 0.5246 & 0.23724 & 0.631 & Normal \\
\hline
\end{tabular}

Based on the table, it can be concluded that the students' autonomy on the control and experimental group are distributed normally. Besides, the result of students' autonomy on both groups show the significance score more than 0.05 which is 0.631 . Therefore, the $H_{o}$ is acceptable and the data is fulfill the assumption for the parametric statistic test.

\section{Homogenity Test}

The result of the homogeneous students' autonomy of the control and experimental groups are shown in this following table.

Table 9. The Result of Students' Autonomy Homogeneous Test

\begin{tabular}{cccccc}
\hline \multirow{2}{*}{$\begin{array}{c}\text { Gain Score Control } \\
\text { and Experiment Class }\end{array}$} & $\begin{array}{c}\text { Levene } \\
\text { Statistic }\end{array}$ & df1 & df2 & Sig. $(p)$ & Information \\
\cline { 2 - 6 } & 0.104 & 1 & 77 & 0.748 & Homogen \\
\hline
\end{tabular}

Based on the table, the significance score of the students' autonomy is more than 0.05 . The significance score of the students' autonomy on the control and experimental group are 0.748 . Thus, based on the result of the homogeneity test, the $\mathrm{H}_{\mathrm{o}}$ is accepted because the significance score of the pre-test and post-test for both groups show significance score more than 0.05 . It means that there is no difference on the data variant or the data is from the same group. 
Formatif: Jurnal Ilmiah Pendidikan MIPA

Vol. 9, No. 4, December 2019, pp. 291-304

p-ISSN: 2088-351X

e-ISSN: 2502-5457

DOI: http://dx.doi.org/10.30998/formatif.v9i4.3522

The data of the research has full filled the prerequisite tests which are the normality test and homogeneity test. Then, the data is analyzed by the comparative test or $\mathrm{t}$ test. The comparative test is done in order to find out the difference before and after using computer based instruction simulation model based on the interactive multimedia or the difference of the control and experimental group. The comparative test is done by using Independent Sample T-test with SPSS 20 for Windows program.

\section{Independent Sample T-test}

Independent Sample T-test is used to find out the difference of the students' autonomy on the control and experimental group. The result of the Independent Sample T-test is described along with these following hypothesis.

$\mathrm{H}_{\mathrm{o}}=$ There is no significance difference on the observation score of students' autonomy in the control and experimental group. It means, the use of computer based instruction simulation model based on the interactive media does not significantly affect the students' autonomy.

$\mathrm{H}_{\mathrm{a}}=$ There is a significance difference on the observation score of students' autonomy in the control and experimental group. It means, the use of computer based instruction simulation model based on the interactive media significantly affects the students' autonomy.

After making the hypothesis, the researcher does the comparative test. The result of the Independent Sample T-test on the students' autonomy is described in this following table.

Table 10. The Result of Independent Sample T-test on the Students' Autonomy

\begin{tabular}{lrrc}
\hline Student's Authonomy Gain Standard & \multicolumn{3}{c}{ Independent Sample T-test } \\
\cline { 2 - 4 } \multicolumn{1}{c}{ Score } & & $\mathrm{df}$ & Sig. $(p)$ \\
\hline Equal Variances assumed & -2.241 & 77 & 0.028 \\
Equal Variances not assumed & -2.208 & 42.438 & 0.033 \\
\hline
\end{tabular}

\section{Discussion}

Based on the table, the Independent Sample T-test on the students' autonomy shows the significance score $(p)<0.05$ which means the $\mathrm{H}_{\mathrm{o}}$ is rejected. The result shows that there is a significance difference on the leaners' autonomy improvement of the experimental and control group.

The previous research methods have applied the computer based instruction simulation model based on the interactive multimedia in order to improve the students' autonomy, especially on the $8^{\text {th }}$ theme "Daerah Tempat Tinggalku". The interactive media consists of the title, instruction, learning objective, learning materials, evaluation, and the conclusion. 
Formatif: Jurnal Ilmiah Pendidikan MIPA

Vol. 9, No. 4, December 2019, pp. 291-304

p-ISSN: 2088-351X

e-ISSN: 2502-5457

DOI: http://dx.doi.org/10.30998/formatif.v9i4.3522

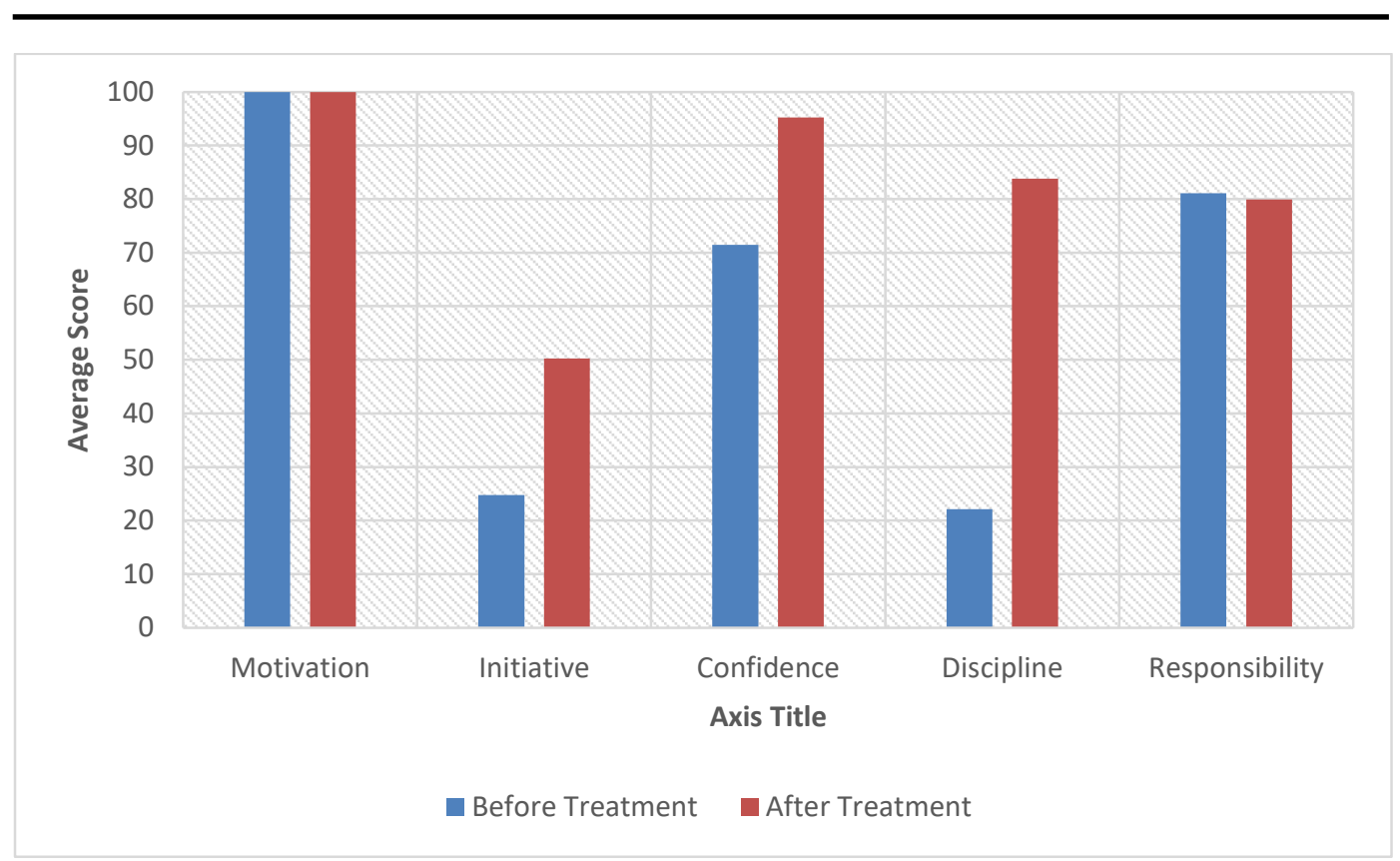

Figure 10. Results Pre-test and Post-test Students’ Autonomy in Experiment Group

As seen from the graphic above, the most outstanding indicator is the $4^{\text {th }}$ indicator about discipline where the score is only 22.14 for the pre-test. Meanwhile, for the post-test, the score significantly improves on the number of 83.88. The students' discipline is seen from how they obey the rules in the class, they do not disturb others during the learning activity, and they directly do their test or the given exercise. It in accordance with the statement by Winter et al., who states that computer based instruction helps the student to plan, monitor, and control their learning effectively (Winter, 2018)

Besides, the $2^{\text {nd }}$ indicator about initiative also significantly improves where the score is only 24.68 for the pre-test but the score is 50.21 for the post-test. The improvement can be seen from several things such as students actively ask question related to their struggling in learning, students help each other student, and the students also actively give opinion when the teacher asks them.

The $3^{\text {rd }}$ indicator about confidence also shows the significance improvement where the score for the pre-test is 71.65 and the score for the post-test is 95.2. The leaners' confidence improvement can be seen from some things such as the students finish their test by themselves, leaners are able to participate on the computer based instruction learning, and students do not depend on others. In addition, the graphic indicates that the $1^{\text {st }}$ and $5^{\text {th }}$ indicator do not show any significance improvement since the score of the pre-test and post-test are almost similar.

Computer based instruction simulation model based on the developed interactive multimedia is announced eligible by the experts who are the expert of material and the expert of media. The validation result on the eligibility of the product is seen from the product assessment. According to the expert material, the average score for the product is 93 which is categorized as "good". Then, the expert of media assesses the product with the average score of 81 which is also categorized as "good". Based on the suggestions from the experts, the researcher revises the product and the revised product is then tested. The test is aimed for knowing the effectiveness of the product computer based instruction simulation model based on the interactive multimedia in improving the students' autonomy with the result of $(\mathrm{p})<0.05$ so the result will be there is a significance difference on the control and experimental group. 
Formatif: Jurnal Ilmiah Pendidikan MIPA

Vol. 9, No. 4, December 2019, pp. 291-304

p-ISSN: 2088-351X

e-ISSN: 2502-5457

DOI: http://dx.doi.org/10.30998/formatif.v9i4.3522

Computer based instruction simulation model based on the interactive multimedia can improve the students' autonomy with the principle of the computer based instruction itself which is independent learning oriented. It is in accordance with Goldstein who states that computer based instruction simulation model creates a learning environment which demands the independent and interactive learning so there is a satisfaction towards each students' learning method (Petty, et.al., 2007). The improvement of the students' autonomy by the use of computer based instruction is also stated by Rusman. He says that computer based instruction is individual so it requires an independent learning (Rusman, 2013). It is in accordance with the statement by Handal and Herrington who state that the hypermedia instructional environments are more likely to engage the students' autonomy on its cognitive field (Handal \& Herrington, 2004). Muraina, Adeleke, and Rahman also state that the students who are taught by applying computer assisted instructional are more independent and they attend one hour per week for discussion sessions without any lecture even without paper textbooks and reference used (Muraina, et.al., 2012). In addition, Warschauer say that the electronic discussion boards, including the computer based instruction, allow the students to participate actively and it encourages the reflection and interaction for the students (Cain \& Pitre, 2003). The encouragement towards students' reflection and interaction is the part of students' autonomy. Based on the statement, it can be concluded that the computer based instruction has positive effect to the students' autonomy. Furthermore, the computer based instruction is done independently where the teacher only acts as the facilitator and mediator because the learning experiences are wrapped up in the computer based instruction program where the students do it independently. Thus, the decision in choosing computer based instruction simulation model based on an interactive multimedia successfully gives positive impacts in improving students' autonomy.

\section{CONCLUSION}

As the conclusion, the use of computer based instruction simulation model based on the interactive multimedia improves the autonomy of the student who are the primary school students of the $4^{\text {th }}$ grade. Computer based instruction simulation model based on the interactive multimedia can be used by the primary school teacher in order to improve the result of the students' learning. In additional, it also improves the affective aspect, for example improving the students' motivation in learning. Computer based instruction simulation model based on the interactive multimedia can also be a reference for the future researcher. In the future study, the product can be developed in different form of product such as tutorial model, instructional games model, and drill and practice model.

\section{REFERENCES}

Azwar, S. (2013). Tes Prestasi Fungsi dan Pengembangan Pengukuran Prestasi Belajar. Yogyakarta: Pustaka Pelajar.

Cain, D.L., \& Pitre, P.E. (2003). The effect of computer mediated conferencing and computer assisted instruction on student learning outcomes. Journal of Asynchronous Learning Networks, 12, 3-4. http://doi.org/10.24059/olj.v12i34.1682

Center on Technology and Disability. Learning with Computer Games and Simulations. New York: American Institutes for Research. 
Formatif: Jurnal Ilmiah Pendidikan MIPA

Vol. 9, No. 4, December 2019, pp. 291-304

p-ISSN: 2088-351X

e-ISSN: 2502-5457

DOI: http://dx.doi.org/10.30998/formatif.v9i4.3522

Darmawan, D. (2012). Inovasi Pendidikan. Bandung: PT Remaja Rosdakarya

Hake, R. R. (2017). Design-based research in physics education: A review. Semanticscholar, 1(1). http://doi.org/10.4324/9781315759593-42

Handal, B., \& Herrington, A. (2004). On Being dependent or independent in computer based learning environments. e-Journal of Instructional Science and Technology, $7(2)$.

Heinich, R., Molenda, M., Russell, J.D., \& Smaldino. (2002). Instructional Media and Technologies for Learning $\left(7^{\text {th }}\right)$. New Jersey: The Lehigh Press.

Kozma, R. B. (1994). The influence of media on learning: The debate continues a new look at the question. $S L M Q, 22(4)$.

Lai, C. C. (2006). The advantages and disadvantages of computer technology in second language acquisition. National Journal for Publishing and Mentoring Doctoral Student Research, 3(1), 1-6.

Mayer, R. E., \& Moreno, R. (2002). Aids to computer-based multimedia learning. Learning and Instruction, 12(1), 107-119. https://doi.org/10.1016/S0959-4752(01)00018-4

Muraina, I.O., Adeleke, I.A., \& Rahman, M.A. (2012). Computer assisted instruction for teaching/learning process and its effects on students' performance in tertiary institutions. International Journal of Computer Trends and Technology.

Regulation of the Minister of National Education. (2016). Peraturan Menteri Pendidikan dan Kebudayaan Republik Indonesia Nomor 22, Tahun 2016, tentang Standar Proses Pendidikan Dasar dan Menengah. Jakarta: Sekretaris Kabinet Republik Indonesia.

Presidential Decree. (2017). Peraturan Presiden Republik Indonesia Nomor 87, Tahun 2017, tentang Penguatan Pendidkan Karakter. Jakarta: Sekretaris Kabinet Republik Indonesia.

Petty, G. C., Lim, D. H., \& Zulauf, J. (2007). Training transfer between cd-rom based instruction and traditional classroom instruction. Journal of Technology Studies 33(1), 48-56. http://doi.org/10.21061/jots.v33i1.a.7

Pichugova, I. L., Stepura, S. N., \& Pravosudov, M. M. (2016). Issues of promoting learner autonomy in EFL context. SHS Web of Conferences, 28, 1-5. http://doi.org/10.1051/ SHS 28 shsconf/201628010 RPTSS 201581

Riduwan. (2010). Skala Pengukuran Variabel-variabel Penelitian. Bandung: Aplhabeta.

Rusman. (2013). Belajar dan Pembelajaran Berbasis Komputer Mengembangkan Profesionalisme Abad 21. Bandung: Alfabeta

Sugar, W., \& Brown, A. (2008). Antecedents of computer based instruction and its current relationship to our discipline: An examination of last fifty years of DAVI/AECT convention presentations. TechTrends, 52(2), 59-69. https://doi.org/10.1007/s11528-008-0137-x

Sugiyono. (2014). Metode Penelitian Kuantitatif, Kualitatif, dan R\&D. Bandung: Alfabeta.

Tabor, S. W., \& Minch, R. P. (2013). Student adoption \& development of digital learning media: Action research and recommended practices. Journal of Information Technology Education Research, 12, 203-223.

Winter, F. I., Greene, J. A., \& Costich, C. M. (2018). Self-regulation of learning within computer-based learning environments: A critical analysis. Education Psychoogyl Rev 20(4), 429-444. http://dx.doi.org/10.1007/s10648-008-9080-9 